\title{
Utilization of dietary glucose in the metabolic syndrome
}

Marià Alemany ${ }^{1,2}$

\begin{abstract}
This review is focused on the fate of dietary glucose under conditions of chronically high energy (largely fat) intake, evolving into the metabolic syndrome. We are adapted to carbohydrate-rich diets similar to those of our ancestors. Glucose is the main energy staple, but fats are our main energy reserves. Starvation drastically reduces glucose availability, forcing the body to shift to fatty acids as main energy substrate, sparing glucose and amino acids. We are not prepared for excess dietary energy, our main defenses being decreased food intake and increased energy expenditure, largely enhanced metabolic activity and thermogenesis. High lipid availability is a powerful factor decreasing glucose and amino acid oxidation. Present-day diets are often hyperenergetic, high on lipids, with abundant protein and limited amounts of starchy carbohydrates. Dietary lipids favor their metabolic processing, saving glucose, which additionally spares amino acids. The glucose excess elicits hyperinsulinemia, which may derive, in the end, into insulin resistance. The available systems of energy disposal could not cope with the excess of substrates, since they are geared for saving not for spendthrift, which results in an unbearable overload of the storage mechanisms. Adipose tissue is the last energy sink, it has to store the energy that cannot be used otherwise. However, adipose tissue growth also has limits, and the excess of energy induces inflammation, helped by the ineffective intervention of the immune system. However, even under this acute situation, the excess of glucose remains, favoring its final conversion to fat. The sum of inflammatory signals and deranged substrate handling induce most of the metabolic syndrome traits: insulin resistance, obesity, diabetes, liver steatosis, hyperlipidemia and their compounded combined effects. Thus, a maintained excess of energy in the diet may result in difficulties in the disposal of glucose, eliciting inflammation and the development of the metabolic syndrome
\end{abstract}

Keywords: metabolic syndrome, insulin resistance, adipose tissue, hyperlipidemia, glycolysis, glucose fate

\section{Review}

\section{Diet and the availability of nutrients}

Present-day humans are adapted to eat a varied omnivorous diet, in which starches provide the largest share of energy; body physiological systems are adapted to this diet, coincident with that consumed by primitive humans [1,2]. Through evolution, we have evolved mechanisms to maximize the use of available food energy, largely plant material, and to store part of the energy as lipid for use in periods of scarcity. However, most of today's diets do not conform to this pattern, largely because of the application of the same mechanisms

\footnotetext{
Correspondence: malemany@ub.edu

'Department of Nutrition and Food Science, Faculty of Biology, University of Barcelona, Barcelona, Spain

Full list of author information is available at the end of the article
}

of food selection that helped us survive [3,4]: The current availability of high-energy lipid-rich diets, containing additional high-biological quality protein, is compounded by cortical signals inducing their consumption because of their palatability [5] and atavistic traits of craving for food containing scarce and/or highenergy nutrients [6,7]. Consequently, energy intake tends to be higher than that needed to fulfill the energy -and plastic- nutrient needs, creating a floating excess of nutrients, which should be processed and disposed of. The physiologically established mechanism for excess nutrient energy removal is thermogenesis [8-10], carried out by the uncoupling protein system of brown adipose tissue (BAT) [11], but also by thyroid-induced organ insufficiency $[12,13]$, increased energy expenditure through protein turnover, and other metabolic activities
C Biomed Central

(c) 2011 Alemany; licensee BioMed Central Ltd. This is an Open Access article distributed under the terms of the Creative Commons Attribution License (http://creativecommons.org/licenses/by/2.0), which permits unrestricted use, distribution, and reproduction in any medium, provided the original work is properly cited. 
$[14,15]$. These mechanisms tend to reduce the excessive buildup of dietary fatty acids and glucose, but are of only limited effect on excess amino acids because of the additional need to remove amino nitrogen.

The elimination of excess glucose also poses a few problems by itself. Glucose is the main inter-organ energy staple, and is released in large amounts by the intestine-portal vein-liver system because the main dietary component is supposed to be starch, which digestion yields glucose. The absence of dietary glucose is a physiological signal in itself, a correlate of starvation, and elicits the mobilization of lipid stores $[16,17]$ to cover the body energy needs. Thus, high lipid availability is construed as a sham "starvation-like condition", which prevents the massive oxidation of glucose [18]. Evidently, excess lipid availability because consumption of high-fat diets is not akin to real starvation or energy deficit, but the preservation of glucose stands; furthermore, high glucose and energy availability enhance the protection of dietary amino acids (paradoxically also in excess) from their utilization as energy substrates $[19,20]$.

The combination of excess fatty acids and excess glucose poses a serious problem to the homoeostatic maintenance of energy balance, a condition unique to the metabolic syndrome (MS) $[21,22]$. The body has to find ways to circumvent the strict glucose preservation measures painstakingly developed and established through evolution for its own protection, such as insulin resistance [23,24].

In the present review, these processes and effects are shown as both homoeostatic control systems and pathogenic mechanisms in the development of the metabolic syndrome,

\section{Excess glucose and insulin resistance}

After insulin resistance denies its entry to muscle, and decreased blood flow restricts adipose tissue uptake, most of the remaining glucose could only be used in significant amounts by BAT (to sustain thermogenesis and for lipid storage) [25], or by the liver, the intestine and -perhaps- by the microbiota. The liver capacity to eliminate excess glucose is limited because of space availability constrictions to glycogen and lipid storage [26]. However, lipogenesis has to be carried out, even countercurrent, because of an already large excess of dietary fatty acids and triacylglycerols, temporarily stored in the liver, waiting for their eventual release as VLDL. A large excess of non-exported energy (lipid, glucose) may help induce liver steatosis, damaging liver function [27]. High insulin helps drive excess glucose towards lipogenesis [28], but the process is also limited by the already excessive availability of acetyl-CoA, which cannot be converted into ketone bodies via 3-hydroxy-
3-methyl-glutaryl-CoA because the high levels of glucose fully inhibit the ketone pathway [29]. As a consequence, glucose levels keep rising and/or are maintained high. Let's look now where the unwanted glucose may go.

BAT enhanced consumption of glucose may represent a quantitatively significant possibility for rodents, but it is doubtful that in humans, with a limited BAT presence $[30,31]$, it may represent a significant dent in the pool of excess circulating glucose, especially when BAT preferred substrate is, again, lipid [32].

Excess glucose becomes a danger by itself: can affect water balance because of its osmotic properties [33], and increase the glycation (and consequent loss in function) of a number of proteins, especially those in contact with the bloodstream [34]. Thus, over a certain limit, excess glucose may be lost via urine. However, before these drastic measures are taken, the body tries to correct glycemia using the whole set of instruments devised to maintain glycemic homoeostasis. High glucose levels decrease appetite [35] and thus limit the intake of food (in the end, of glucose). However, this effect is largely dependent on insulin levels and function [36], which is in turn affected by excess lipid and other insulin resistance-inducing factors [37].

Glucose entry into most cells is controlled by insulin, thus alteration of its function starves cells from access to glucose, even in front of high blood glucose, and altering tissue glycogen [38]. Control of glucose utilization by the liver relies not in transport, but on its phosphorylation, in a way that regulation of glucokinase is critical [39], but the insulin-controlled catabolism of hexoses through the glycolytic and pentose-phosphate pathways to finally -and irreversibly- yield acetyl-CoA are also critical $[40,41]$. The ability of the liver to store glucose as glycogen or to transform it into acetyl-CoA (for oxidation of lipid synthesis) is limited, and cannot cope with the excess glucose left over by the preferential consumption of lipid. Where goes, then the postulated excess of glucose?

Diabetes (type 2) and its principal cause/symptom, insulin resistance, are widely considered the core pathological trait defining the metabolic syndrome [42]. This is because insulin resistance increases both glycemia and insulinaemia, favoring the deposition of fat [43], and increasing the circulating lipids [44] which help raise arterial tension when combined [45]. These diseases are complementary and act synergistically in deranging the metabolic control of energy utilization [46].

Insulin resistance is closely related to excess fatty acid availability $[47,48]$, and facilitates the deposition of fat in adipose and other tissues [49]. Muscle insulin resistance is in fact a defensive mechanism converted in a deadly trap by excessive availability of energy. Under normal 
conditions of limited energy availability, glycemia is low (scarce supply) and in consequence, glucose is not taken up by most tissues, being reserved for nerve tissue [50] and glycolytic red blood cells [51]. Under these conditions, lipids from the body reserves are mobilized, and ketone bodies [52] and fatty acids are made available (NEFA or fatty acids released by lipoprotein lipase activity) to the muscle. Their presence inhibits the insulin signaling cascade [53] which limits the release of GLUT4 rafts to the cell surface [54], thus effectively diminishing glucose uptake in favor of fatty acids [55].

Under conditions of excess energy available (i.e. abundant fatty acids and glucose), the effects exerted by fatty acids are the same. Consequently, the unused glucose (there is no need now to preserve it) builds up in blood. Hyperglycemia elicits the secretion of insulin by the pancreas; the ensuing hiperinsulinemia tries to counter the muscle insulin resistance. However, the combination of hiperinsulinemia and insulin resistance facilitates/ induces the entry of glucose in tissues less protected than muscle. High insulinemia and high glycemia persist because most of the blood glucose, remains unused, has no place taking it up and using it in quantity. In rodents, this excess glucose is largely converted into fat by the liver and adipose tissue [56], thus aggravating the problem of substrate utilization by muscle and other peripheral tissues. In humans there is little lipogenesis from glucose under normal conditions $[57,58]$, thus the problem of disposal of excess glucose is even greater than in rodents. However, the active production of $3 \mathrm{C}$ fragments by peripheral tissues, such as WAT $[59,60]$, provides the liver with substrates for either gluconeogenesis in part blocked by excess glucose [61] or lipogenesis [62]. High 3C fragment availability potentiates hepatic lipogenesis $[63,64]$ and may explain, at least in part, the increased production of fatty acids from excess glucose.

Dietary limitation of low glycemic index carbohydrates, but essentially decreased total energy input, may help improve the condition of the MS $[65,66]$ by diminishing the excess of energy/substrates to dispose of, but also by flattening the curve of absorption of glucose from the gut, and thus decreasing the insulin response [67].

\section{The fate of excess glucose}

Increased BAT [68] and muscle [69] thermogenesis can help eliminate a sizeable part of the excess unused dietary glucose. This may be, probably helped by the combination of limited muscle and adipose tissue glucose oxidation [70], liver utilization for lipid synthesis [28] and energy utilization, including thermogenesis [71], futile cycling and thyroid hormone-elicited loss of hepatic mitochondrial efficiency [72]. These energy-spending processes may also help diminish the amino acid load, but probably to a lesser extent because of the constrictions posed by the need to eliminate their amino nitrogen [73].

In addition to the processes presented above, other possible pathways for glucose disposal should be explored. Glucose freely diffuses across the intestinal wall (i.e. both ways) [74] and the total daily volume of digestive secretions is considerable; several fold higher than total volemia. Food-derived sugars are actively metabolized by the microbiota [75]. We can thus expect that an undetermined part of the excess body glucose may find its way into the intestinal lumen, where it may be taken up and metabolized by the microorganisms. Since the microbiota behaves as a symbiotic adjunct to our digestive system, its eventual participation in the handling of excess substrates may constitute a substantial part of their function under the anomalous conditions of excess energy availability. The "obese microbiota" has a different composition and different metabolic function than that of lean people eating the same diet [76]. There are, thus, factors - not immediately diet-related- that mark the wide differences between microbiota bacterial types of MS and normal individuals $[77,77]$. The NO//nitrate/nitrite question may be a principal factor, but the probable availability of other diffused substrates and their acting as "overflow" energy sink is a question that may help explain part of our newly found adaptation to excess energy.

Thus, human bodies, non adapted to the new evolutionary challenge: excess of nutrients, have found ways to cope, albeit partially, with the problems posed by our deeply ingrained mechanisms of preservation and survival against scarcity rather than by excess itself.

Short-term adaptations: lipogenesis, lipid oxidation, fat deposition, cannot be maintained indefinitely; others (thermogenesis, turnover, growth) have also a limited span of application. Only long-term adaptations, affecting tissue structure and function, but also shifts in metabolic pathways (e.g. $\mathrm{N}_{2}$ excretion $[78,79]$ ) can be sustainable over a long period. However, in all cases, the adoption of these measures represents a forced operation (adaptation) of mechanisms not devised for these purposes, which bears consequences in the medium and long term by producing the changes we recognize largely as inflammation, the molecular basis of the MS.

Other compensatory mechanisms include the control of insulin secretion by amino acids [80,81], and a shift in the main insulin deactivation site. Under standard conditions, the liver breaks up a large part of the insulin it receives through the portal vein $[82,83]$, the normal pancreatic blood outlet; however, in hyperglycemic obesity, the liver cannot remove a large portion of this insulin, with the consequence of permanently raised 
systemic insulinemia [84]. A number of tissues, such as white adipose tissue (WAT), however, develop the ability to deactivate a significant proportion of the insulin carried by the blood $[84,85]$, a mechanism that protects the tissues themselves of being force-fed an unwanted and not metabolizable (because of saturation of normal pathways) load of glucose. This may help protect the adipose tissue, but overall aggravates the problem of glucose disposal and the growing contest between increasing glucose and insulin levels.

\section{Hepatic steatosis and hyperlipidemia}

In the MS, cholesterol synthesis prevails over its uptake from the bloodstream [86]. Hepatic steatosis reduces the functionality of the liver, increasing the synthesis of cholesterol [87], whilst liver cholesterol uptake is impaired because of defective insulin signaling [88]. There is a decrease in circulating HDL-cholesterol [89] but an increase in that carried by LDL $[90,91]$. Liver altered function, i.e. decreased insulin removal [92] and blocked ketone body synthesis [93] indirectly favor cholesterol synthesis [94] and decreased liver uptake from plasma lipoproteins [95], which adds to the problem of hypercholesterolemia.

In liver steatosis, protein synthesis is also altered, not for lack of amino acids or energy, but because of lipid clogging and cell damage $[96,97]$, which in turn elicits the proliferation of defense immune cells that additionally intervene in the already stretched hepatic function [98]. A probable key element in the development of liver steatosis is endoplasmic reticulum stress $[99,100]$, since in liver, this cell organelle system exerts a number of functions [101,102], largely related with lipogenesis and the synthesis of complex lipids [103], but also the synthesis (folding) of proteins that will be later assembled with lipid in the dyctiosomes for export as circulating proteins or lipoproteins [104]. Alteration of the redox state or an unbalanced availability of nutrients, such as those constantly affecting the liver in the MS, may elicit an altered endoplasmic reticulum response, the breakup of the assembly line for lipoproteins and the accumulation of fat in the liver [105].

Excess peripheral production of free radicals and the oxidation of lipoproteins [106] may combine with the damage to the liver because of excess lipid accumulation to decrease its capacity to process xenobiotics [107]. The fairly constant presence of increased uric acid in plasma in the MS $[108,109]$ indicates that xanthine oxidase activity is increased [110] helping sustain oxidative damage. It has been suggested that a relative deficit in minerals may help aggravate the situation, that is the case for magnesium [111] and, especially, zinc [112]. This in turn affects -in different ways- the metabolism of iron [113-115].

\section{Adipose tissue and hyperglycemia}

In WAT there is a large production of lactate under conditions of insulin resistance elicited by excess fatty acids [116], which is another consequence of hyperlipidemia, excess lipid consumption and the presence in the system of more energy than needed (and which the human machinery is able to eliminate) [117]. Insulin resistance effectively decreases the muscle ability to take up glucose [55]; it does not affect brain glucose uptake, and neither does overload the liver, which lets glucose pass through undisturbed or uses it for lipogenesis (to add insult to injury, but to somehow limit the dangers of excess glucose) [118]. One of the few remaining sites large enough to use this excess glucose is adipose tissue, which despite being far from uniform in cell size, translating ability and metabolic activity [119] contains small but dynamic glycogen stores [120], fairly sensitive to catecholamines [121]. WAT is able to incorporate glucose from the blood even under conditions of insulin resistance [122,123]. This glucose may be used to produce more lactate (as observed in the obese) [60] to obtain the ATP needed for cell function under conditions of varying degrees of hypoxia [124]. However, a large portion of excess glucose finds its way into lipogenesis [125].

Hyperglycemia (and hyperinsulinemia) force WAT to take up a large part of the glucose waived off by other tissues. The logical path is the glycolytic conversion to pyruvate, which may be increased under hypoxic or anoxic conditions (i.e. with scarcely operative mitochondrial oxidative systems) as the main source of ATP. A small part of this glucose is stored as glycogen, which can be easily mobilized to produce glycolytic energy even under hypoxia [126]. But under these conditions, WAT generates an excess of acetyl-CoA, in part because of the operation of pyruvate dehydrogenase [127], but also from sporadic lipolysis elicited by catecholamine stimulation, such as that of exercise [128]; this process also activates the phosphorolysis of glycogen [129], increasing the availability of cytosolic hexoses-phosphate, and then of pyruvate. Acetyl-CoA could not be oxidized at a fast rate because of hypoxia and Krebs cycle (NADH) saturation. Under these circumstances: pyruvate dehydrogenase could not operate, causing a buildup of pyruvate/lactate and the release of the latter to the bloodstream $[130,131]$, which generates an acidotic microenvironment in WAT, especially after adrenergic stimulation (even when mild, such as that induced by exercise) [132]. This lactate (and the corresponding lowering of blood $\mathrm{pH}$ ) adds to the erythrocyte glycolysis, forcing the dissociation of oxygen from oxyhemoglobin [133].

The alteration of adipocyte (or macrophage) redox equilibrium may trigger also a situation of endoplasmic 
reticulum stress [134], which may compound the severe condition of the cells by further limiting lipogenesis and protein synthesis [135], and/or altering the immune response of the tissue (in the case of macrophages) [136].

Body energy expenditure is largely dependent on the flow of blood across the cells, enhancing their ability to interchange substrates, gases and other compounds with the bloodstream [137]. Thus, we must take consider the critical importance of blood flow across the ultimate energy sink that is adipose tissue. The lack of protection of WAT against the avalanche of lipids results into a massive enlargement of WAT lipid vacuoles. The hypertrophied tissue exerts pressure on itself and its surrounding structures, limiting -again- blood flow and, perhaps, further generating hypoxia [138].

However, this acute handling of a punctual excess of energy cannot be indefinitely maintained, day after day for a lifetime, since there are physical constraints to the unchecked size increase of WAT. In fact this limit is achieved at fairly different WAT sizes for different WAT sites and individuals, which means that the tale is not complete and that there exist additional factors which protect WAT from unstoppable growth to death [139]

\section{White adipose tissue, the last energy sink}

WAT shares with BAT the ability to store large amounts of fat; their main difference being the higher oxidative capacity of BAT, and its idiosyncratic capability of wasting energy under tight nervous/endocrine control [140-142]. WAT is (as BAT) also a disperse organ [143,144], but most of WAT is concentrated in a small number of large masses, which purported main role is that of storing most of the body energy reserves in the form of triacylglycerols $[145,146]$. However, WAT also plays other functions, such as insulating, filling spaces, and physically protecting structures [59] controls some functions of their adjacent organs $[147,148]$, as is the case of intermuscular, epicardial or perivascular WAT $[149,150]$. WAT is a rallying center for immune system cells $[151,152]$, and provides stem cells for repair, regeneration or adaptive modulation [153,154]. However, probably its main role functions are its ability to store large amounts of fat and its direct implication in the control of energy partitioning and handling energy (together with the liver) under conditions of scarcity [146]. Location, in this case, equals specialization, since mesenteric WAT has a very direct implication in the handling of lipids absorbed by the intestine [155], whilst other depots (retroperitoneal, perigonadal, gluteal), with larger cells and lower overall metabolic activity play a role more adjusted to that of storage of lipid reserves [156]. Adipose tissue distribution shows marked sex-related differences $[157,158]$, which hint to a role of sex steroid hormones in the modulation of the long-term manifestation of the MS.

There are two other important distinguishing points for WAT in comparison with all other tissues: first, WAT is not as protected against insulin-mediated glucose incorporation as are muscle [159] and the liver [160], since WAT is the last stop for circulating energy substrates (glucose, triacylglycerols). WAT has to take in what all other organs or tissues could not use, since it acts largely as energy buffer, to accumulate excess energy in times of affluence and to release them in scarcity. The second important difference is its ability to considerably increase its mass within the physiological range conditions [161]; only very large -and permanentincreases in overall WAT mass (i.e. in the lipid it contains) becomes a pathological condition: obesity.

WAT has considerable flexibility in distribution, cell types and numbers, mass, lipid content, and ability to store energy $[162,163]$. Its main reserves are triacylglycerols [164]. Nevertheless, -at least in the obese, with large WAT mass- it also deeply influences glucose metabolism, storing glycogen and releasing lactate/pyruvate in accordance with daily prandial cycles $[59,120]$. WAT is a well known source of hormones, it synthesizes and recycles estrone [165], and is able to interchange both estrone/estradiol and androstenedione/testosterone $[166,167]$, as well as cortisol/cortisone (corticosterone/ dehydrocorticosterone in rodents) [168]. WAT also produces a number of adipocytokines that control the response to energy challenges of the tissue itself and surrounding tissues $[138,148]$, i.e. has both paracrine and endocrine secretions. WAT is the main organ synthesizing leptin [169], a small peptide hormone which controls gonadotropin secretion $[170,171]$, inducing the preparation for full functional reproductive capacity. Leptin also plays an important role in the control of food intake $[172,173]$ and body energy handling [174-176]. The complexity of WAT in the paracrine regulation of energy partition and its own size and cell distribution is exemplified by the presence of a complete rennin-angiotensin system [177], and the synthesis of other adipokines such as adiponectin $[178,179]$. Adiponectin is a powerful anti-inflammatory cytokine $[179,180]$, which also participates in the maintenance of energy balance and substrate utilization control [181], and which effects are projected to other tissues $[182,183]$.

WAT is one of the body tissues with highest ability to regenerate from stem cells to preadipocytes and fully developed adipocytes [184], depending on the demands for energy storage; cell size may change several-fold because of the often enormous accumulation of triacylglycerols [161], which routinely accounts for up to $85 \%$ 
of the fresh tissue weight [185]. WAT cell numbers can also decrease rapidly when storage space is not needed: selective apoptosis mechanisms cull down the number of adipose tissue cells [186]. This high versatility, and WAT endocrine function, help to control the mass of lipid energy stored [187-189], in order to make it available to the whole body under conditions of scarcity [161], often in a cyclic way as is the case of migratory birds [190] or the pregnancy/pre-lactation accumulation of fat in mammals [191].

WAT is also the main site of the inflammatory processes $[138,192,193]$ that are at the root of the MS. This is due largely to the reasons indicated above: its role as key energy control player [194], but also to the fact that WAT is the last in the line to dispose of excess energy. Under conditions of plenty, WAT cannot dispose of the excess energy it is forced to store, grows in size, initiates the immune response [195], which is later amplified by invading macrophages [196,197], and thus obesity develops.

\section{Conclusion}

Excess energy intake is primarily countered by the normal homeostatic mechanisms regulating body weight: signals eliciting a decrease in food intake combined with increased energy expenditure, i.e. higher thermogenesis, increased metabolic activity (including enhanced protein turnover), decreased overall metabolic efficiency (which may be also considered part of the thermogenic process), and, ultimately, increased energy storage. However, continued exposure to high-energy diets may either overcome the possibilities of these systems or/and erode their efficiency, resulting in unbearable excess energy accumulation on the storage depots. The capacity of body organs to store glycogen and fat are limited, and excessive buildup of reserves provokes tissue damage, forcing the intervention of the immune, albeit with little success and considerable (and largely damaging) release of metabolic control signals which compound the problem. The arrest of WAT fat accumulation is obtained at the price of loss of energy partition functionality and lefts the energy partition control system in disarray, conditions that eventually develop in a constellation of metabolic alterations that constitute the MS.

High fatty acid availability, often the consequence of high-energy diets rich in fats, compound the already high digestive process-generated availability of glucose by eliciting insulin resistance. The large excess of glucose thus generated is largely used to promote energyconsuming processes and may result, in a significant part, converted to lipid for storage; or, in the case of coexistent high dietary fat, used for immediate disposal to prevent hyperglycemia. But even this process has limits and excess glucose damages the liver-adipose tissue energy-maintenance axis, which extends to the whole body because of the implication of defense mechanisms that inadequately try to prevent these damages. The consequences are inflammation and the development of the MS.

\section{List of abbreviations}

WAT: white adipose tissue; BAT: brown adipose tissue; MS: metabolic syndrome

\section{Acknowledgements}

Supported by grant SAF2009-11739 of the Plan Nacional de Investigación en Biomedicina of the Government of Spain.

\section{Author details}

${ }^{1}$ Department of Nutrition and Food Science, Faculty of Biology, University of Barcelona, Barcelona, Spain. ${ }^{2} \mathrm{CIBER}$ Obesity and Nutrition, Institute of Health Carlos III, Spain.

\section{Competing interests}

The author declares that he has no competing interests.

Received: 20 September 2011 Accepted: 26 October 2011

Published: 26 October 2011

\section{References}

1. Eaton SB, Konner M: Palaeolithic nutrition. A consideration of its nature and current implications. N Engl J Med 1985, 312:283-289.

2. Eaton SB, Eaton SB: Paleolithic vs. modern diets - selected pathophysiological implications. Eur J Nutr 2000, 39:67-70.

3. Sørensen LB, Møller P, Flint A, Martens M, Raben A: Effect of sensory perception of foods on appetite and food intake: a review of studies on humans. Int J Obesity 2003, 27:1152-1166.

4. Zheng $H$, Lenard NR, Shin AC, Berthoud HR: Appetite control and energy balance regulation in the modern world: reward-driven brain overrides repletion signals. Int J Obesity 2009, 33:S8-S13.

5. Blundell JE, Lawton CL, Cotton JR, Macdiarmid Jl: Control of human appetite: Implications for the intake of dietary fat. Annu Rev Nutr 1996, 16:285-319.

6. Yanovski S: Sugar and fat: cravings and aversions. J Nutr 2003, 133:835S-837S.

7. Pickering C, Alsiö J, Hulting AL, Schiöth HB: Withdrawal from free-choice high-fat high-sugar diet induces craving only in obesity-prone animals. Psychopharmacol 2009, 204:431-443.

8. Schutz Y, Acheson KJ, Jequier E: 24-Hour energy expenditure and thermogenesis. Response to progressive carbohydrate overfeeding in man. Int J Obesity 1985, 9:111-114.

9. Atrens DM, Holmes LJ, Jirasek M, Siviy SM, Solowij N: Hypothalamic modulation of thermogenesis and energy substrate utilization. Brain Res Bull 1987, 18:303-308.

10. Jansky L: Humoral thermogenesis and its role in maintaining energy balance. Physiol Rev 1995, 75:237-259.

11. Ricquier D, Arch J, Bazin R, Bouillaud F, Mory G, Penicaud L, Toumelin P: Expression of uncoupling protein messenger-RNA in thermogenic or weakly thermogenic brown adipose tissue. Evidence for a rapid $\beta$ adrenoreceptor-mediated and transcriptionally regulated step during activation of thermogenesis. J Biol Chem 1986, 261:13905-13910.

12. Bobyleva V, Pazienza TL, Maseroli R, Tomasi A, Salvioli S, Cossarizza A, Franceschi C, Skulachev VP: Decrease in mitochondrial energy couplings by thyroid hormones: a physiological effect rather than a pathological hyperthyroidism consequence. FEBS Lett 1998, 430:409-413.

13. Silvestri E, Schiavo L, Lombardi A, Goglia F: Thyroid hormones as molecular determinants of thermogenesis. Acta Physiol Scand 2005, 184:265-283.

14. Miller BG, Otto WR, Grimble RF, York DA, Taylor TG: The relationship between protein turnover and energy balance in lean and genetically obese (ob/ob) mice. Br J Nutr 1979, 42:185-199. 
15. Zurlo F, Larson K, Bogardus C, Ravussin E: Skeletal muscle metabolism is a major determinant of resting energy expenditure. J Clin Invest 1990, 86:1423-1427

16. Saudek SHD, Felig P: The metabolic events of starvation. Am J Med 1976, 60:117-126.

17. Cahill GF: Fuel metabolism in starvation. Annu Rev Nutr 2006, 26:1-22.

18. Romijn JA, Godfried MH, Hommes MJT, Endert E, Sauerwein HP: Decreased glucose oxidation during short term starvation. Metabolism 1990, 39:525-530.

19. Felig P, Owen OE, Wahren J, Cahill GF: Amino acid metabolism during prolonged starvation. J Clin Invest 1969, 48:584-594

20. O'Connell RC, Morgan AP, Aoki TT, Ball MR, Moore FD: Nitrogen conservation in starvation: Graded responses to intravenous glucose. $J$ Clin Endocrinol Metab 1974, 39:555-563.

21. Freedland ES: Role of a critical visceral adipose tissue threshold (CVATT) in metabolic syndrome: implications for controlling dietary carbohydrates: a review. Nutr Metab 2004, 1:12.

22. Skilton MR, Laville M, Cust AE, Moulin P, Bonnet F: The association between dietary macronutrient intake and the prevalence of the metabolic syndrome. Br J Nutr 2008, 100:400-407.

23. Martin JF, Johnston CS, Han CT, Benyshek DC: Nutritional origins of insulin resistance: $A$ rat model for diabetes-prone human populations. J Nutr 2000, 130:741-744.

24. Watve MG, Yajnik CS: Evolutionary origins of insulin resistance: a behavioral switch hypothesis. BMC Evol Biol 2007, 7:61.

25. Young P, Smith SA, Cawthorne MA: Brown adipose tissue is a major site of glucose-utilization in C57B1/6 OB OB mice treated with a thermogenic beta-adrenoceptor agonist. Biochem Biophys Res Commun 1985, 130:241-248

26. Holness MJ, Maclennan PA, Palmer TN, Sugden MC: The disposition of carbohydrate between glycogenesis, lipogenesis and oxidation in liver during the starved-to-fed transition. Biochem J 1988, 252:325-330.

27. de Meijer VE, Le HD, Meisel JA, Sharif MRA, Pan A, Nose V, Puder M: Dietary fat intake promotes the development of hepatic steatosis independently from excess caloric consumption in a murine model. Metabolism Clin Exp 2010, 59:1092-1105.

28. Schwarz JM, Linfoot P, Dare D, Aghajanian K: Hepatic de novo lipogenesis in normoinsulinemic and hyperinsulinemic subjects consuming high-fat, low-carbohydrate and low-fat, high-carbohydrate isoenergetic diets. Am J Clin Nutr 2003, 77:43-50

29. Riou JP, Beylot M, Laville M, de Parscau L, Delinger J, Sautot G, Mornex R: Antiketogenic effect of glucose per se in vivo in man and in vitro in isolated rat liver cells. Metabolism 1986, 35:608-613.

30. Lee P, Greenfield JR, Ho KKY, Fulham MJ: A critical appraisal of the prevalence and metabolic significance of brown adipose tissue in adult humans. Am J Physiol 2010, 299:E601-E606.

31. Ravussin $\mathrm{E}$ : The presence and role of brown fat in adult humans. Curr Diabetes Rep 2010, 10:90-92.

32. McKee G, Andrews JF: Brown adipose tissue lipid is the main source of energy during arousal of the golden hamster (Mesocricetus auratus). Comp Biochem Physiol 1990, 96A:485-488.

33. Christlieb AR, Krolewski AS, Warram JH: Systemic hypertension, diabetes mellitus and the kidney. Am J Cardiol 1987, 60:61-65.

34. Ulrich P, Cerami A: Protein glycation, diabetes and aging. Rec Progr Horm Res 2001, 56:1-22.

35. Flint A, Møller BK, Raben A, Sloth B, Pedersen D, Tetens I, Holst JJ, Astrup A: Glycemic and insulinemic responses as determinants of appetite in humans. Am J Clin Nutr 2006, 84:1365-1373.

36. Woods SC, Lutz TA, Geary N, Langhans W: Pancreatic signals controlling food intake; insulin, glucagon and amylin. Phil Trans Roy Soc Lond B 2006, 361:1219-1235.

37. Anthony K, Reed LJ, Dunn JT, Bingham E, Hopkins D, Marsden PK, Amiel SA: Attenuation of insulin-evoked responses in brain networks controlling appetite and reward in insulin resistance. The cerebral basis for impaired control of food intake in metabolic syndrome? Diabetes 2006, 55:2986-2992.

38. Felber JP, Golay A, Felley C, Jéquier E: Regulation of glucose storage in obesity and diabetes: Metabolic aspects. Diabet Metab Res Rev 1988, 4:691-700.

39. Barzilai N, Rossetti L: Role of glucokinase and glucose-6-phosphatase in the acute and chronic regulation of hepatic glucose fluxes by insulin. $J$ Biol Chem 1993, 268:25019-25025.
40. Kelley DE, Reilly JP, Veneman T, Mandarino LJ: Effects of insulin on skeletal muscle glucose storage, oxidation, and glycolysis in humans. Am J Physiol 1990, 258:E923-E929.

41. Saltiel $A R$, Kahn CR: Insulin signalling and the regulation of glucose and lipid metabolism. Nature 2001, 414:799-806

42. Reusch JEB: Current concepts in insulin resistance, type 2 diabetes mellitus, and the metabolic syndrome. Am J Cardio/ 2002, 90:19G-26G.

43. Després JP: Abdominal obesity as important component of insulinresistance syndrome. Nutrition 1993, 9:452-459.

44. Ayyobi AF, Brunzell JD: Lipoprotein distribution in the metabolic syndrome, type 2 diabetes mellitus, and familial combined hyperlipidemia. Am J Cardiol 2003, 92:27J-33J.

45. Hwu CM, Liou TL, Hsiao LC, Lin MW: Prehypertension is associated with insulin resistance. Q J Med 2009, 102:705-711.

46. Saad MF, Rewers M, Selby J, Howard G, Jinagouda S, Fahmi S, Zaccaro D, Bergman RN, Savage PJ, Haffner SM: Insulin resistance and hypertension The Insulin Resistance Atherosclerosis Study. Hypertension 2004, 43:1324-1331.

47. Haag M, Dippenaar NG: Dietary fats, fatty acids and insulin resistance: short review of a multifaceted connection. Med Sci Monitor 2005, 11: RA359-RA367.

48. Koonen DPY, Sung MMY, Kao CKC, Dolinsky WW, Koves TR, Ilkayeva O, Jacobs RL, Vance DE, Light PE, Muoio DM, Febbraio M, Dyck JRB: Alterations in skeletal muscle fatty acid handling predisposes middleaged mice to diet-induced insulin resistance. Diabetes 2010, 59:1366-1375.

49. Gertow K, Rosell M, Sjogren P, Eriksson P, Vessby B, de Faire U, Hamsten A, Hellenius ML, Fisher RM: Fatty acid handling protein expression in adipose tissue, fatty acid composition of adipose tissue and serum, and markers of insulin resistance. Eur J Clin Nutr 2006, 60:1406-1413.

50. Kato $\mathrm{T}$, Lowry $\mathrm{OH}$ : Enzymes of energy-converting systems in individual mammalian nerve cell bodies. J Neurochem 1973, 20:151-163.

51. Harvey JW, Kaneko JJ: Glucose metabolism of mammalian erythrocytes. J Cell Physiol 1976, 89:219-224.

52. Elia M, Wood S, Khan K, Pullicino E: Ketone body metabolism in lean male adults during short-term starvation, with particular reference to forearm muscle metabolism. Clin Sci 1990, 78:579-584

53. Griffin ME, Marcucci MJ, Cline GW, Bell K, Barucci N, Lee D, Goodyear LJ, Kraegen EW, White MF, Shulman Gl: Free fatty acid-induced insulin resistance is associated with activation of protein kinase $C \theta$ and alterations in the insulin signaling cascade. Diabetes 1999, 48:1270-1274.

54. Mueckler M: Insulin resistance and the disruption of Glut4 trafficking in skeletal muscle. J Clin Invest 2001, 107:1211-1213.

55. Ragheb R, Shanab GML, Medhat AM, Seoudi DM, Adeli K, Fantus IG: Free fatty acid-induced muscle insulin resistance and glucose uptake dysfunction: Evidence for PKC activation and oxidative stress-activated signaling pathways. Biochem Biophys Res Commun 2009, 389:211-216.

56. Herzberg GR, Rogerson M: Interaction of dietary carbohydrate and fat in the regulation of hepatic and extrahepatic lipogenesis in the rat. $\mathrm{Br} J$ Nutr 1988, 59:233-241.

57. Hellerstein MK, Christiansen M, Kaempfer S, Kletke C, Wu K, Reid JS, Mulligan K, Hellerstein NS, Shackleton CH: Measurement of de novo hepatic lipogenesis in humans using stable isotopes. J Clin Invest 1991, 87:1841-1852.

58. Hellerstein MK: De novo lipogenesis in humans: metabolic and regulatory aspects. Eur J Clin Nutr 1999, 53:S53-S65.

59. Hagström $E$, Arner $P$, Ungerstedt $U$, Bolinder J: Subcutaneous adipose tissue: a source of lactate production after glucose ingestion in humans. Am J Physiol 1990, 258:E888-E893.

60. Muñoz S, Franckhauser S, Elias I, Ferré T, Hidalgo A, Monteys AM, Molas M Cerdán S, Pujol A, Ruberte J, Bosch F: Chronically increased glucose uptake by adipose tissue leads to lactate production and improved insulin sensitivity rather than obesity in the mouse. Diabetologia 2010, 53:2417-2430.

61. McDaniel HG: Acute suppression of hepatic gluconeogenesis by glucose in the intact animal. Am J Physiol 1975, 229:1569-1575.

62. Diraison F, Dusserre E, Vidal H, Sothier M, Beylot M: Increased hepatic lipogenesis but decreased expression of lipogenic gene in adipose tissue in human obesity. Am J Physiol 2002, 282:E46-E51.

63. Geelen MJH, Hindriks GA: Studies on the substrate for hepatic lipogenesis in the rat. FEBS Lett 1984, 175:8-12. 
64. Salmon DM, Bowen NL, Hems DA: Synthesis of fatty acids in the perfused mouse liver. Biochem J 1974, 142:611-618.

65. Iannuzzi A, Licenziati MR, Vacca M, de Marco D, Cinquegrana G, Laccetti M, Bresciani A, Covetti G, lannuzzo G, Rubba P, Parillo M: Comparison of two diets of varying glycemic index on carotid subclinical atherosclerosis in obese children. Heart Vess 2009, 24:419-424.

66. de Luis DA, Aller R, Izaola O, Gonzalez Sagrado M, Conde R, Gonzalez JM: Effect of a hypocaloric diet in transaminases in nonalcoholic fatty liver disease and obese patients, relation with insulin resistance. Diabet Res Clin Pract 2008, 79:74-78.

67. Jenkins DJA, Wolever TMS, Collier GR, Ocana A, Rao AV, Buckley G, Lam Y, Mayer A, Thompson LU: Metabolic effects of a low-glycemic-index diet. Am J Clin Nutr 1987, 46:968-975.

68. Ma SWY, Foster DO: Brown adipose tissue, liver, and diet-induced thermogenesis in cafeteria diet-fed rats. Can J Physiol Pharmacol 1989, 67:376-381.

69. Kus V, Prazak T, Brauner P, Hensler M, Kuda O, Flachs P, Janovska P, Medrikova D, Rossmeisl M, Jilkova Z, Stefl B, Pastalkova E, Drahota Z, Houstek J, Kopecky J: Induction of muscle thermogenesis by high-fat diet in mice: association with obesity-resistance. Am J Physiol 2008, 295: E356-E367.

70. Kelley DE, Mandarino $\mathrm{L}$ : Fuel selection in human skeletal muscle in insulin resistance: A reexamination. Diabetes 2000, 49:677-683.

71. Ma SWY, Foster DO, Nadeau BE: Evidence for Liver As the Major Site of the Diet-Induced Thermogenesis of Rats Fed a Cafeteria Diet. Can J Physiol Pharmacol 1987, 65:1802-1804.

72. lossa S, Liverini G, Barletta A: Effect of thyroid state and cold exposure on rat liver mitochondrial protein mass and function. J Endocrinol 1991, 131:67-73.

73. Esteve M, Rafecas I, Fernández-López JA, Remesar X, Alemany M: Dietary amino acid balances in young Wistar rats fed a cafeteria diet. Biochem Mol Biol Int 1993, 29:1069-1081.

74. Levine GM, Shiau YF, Deren JA: Characteristics of intestinal glucose secretion in normal and diabetic rats. Am J Physiol 1982, 242:G455-G459.

75. Kleessen B, Hartmann L, Blaut M: Oligofructose and long-chain inulin: influence on the gut microbial ecology of rats associated with a human faecal flora. Br J Nutr 2001, 86:291-300.

76. Ley RE, Turnbaugh PJ, Klein S, Gordon Jl: Human gut microbes associated with obesity. Nature 2006, 444:1022-1023.

77. Tilg H: Obesity, metabolic syndrome, and microbiota multiple interactions. J Clin Gastroenterol 2010, 44:S16-S18.

78. Costa G, Ullrich L, Kantor F, Holland JF: Production of elemental nitrogen by certain mammals including man. Nature 1988, 218:546-551.

79. Esteve M, Rafecas I, Remesar X, Alemany M: Nitrogen balances of lean and obese Zucker rats subjected to a cafeteria diet. Int J Obesity 1991, 16:237-244.

80. Felig P, Marliss E, Cahill GF: Plasma amino acid levels and insulin secretion in obesity. N Engl J Med 1969, 281:811-816.

81. Efendic S, Cerasi E, Luft R: Quantitative study on the potentiating effect of arginine on glucose-induced insulin response in healthy, prediabetic, and diabetic subjects. Diabetes 1974, 23:161-171.

82. Pease RJ, Smith GD, Peters TJ: Characterization of insulin degradation by rat-liver low-density vesicles. Eur J Biochem 1987, 164:251-257.

83. Misbin Rl, Merimee TJ, Lowenstein JM: Insulin removal by isolated perfused rat liver. Am J Physiol 1976, 230:171-177.

84. Ardevol A, Adan C, Canas X, Rafecas I, Esteve M, Remesar X FernandezLopez JA, Alemany M: Adipose tissue extraction of circulating insulin in anaesthetized Zucker obese rats. Int J Obesity 1996, 20:837-841.

85. Rafecas I, FernandezLopez JA, Salinas I, Formiguera X, Remesar X, Foz M, Alemany M: Insulin degradation by adipose tissue is increased in human obesity. J Clin Endocrinol Metab 1995, 80:693-695.

86. Gylling $\mathrm{H}$, Hallikainen $\mathrm{M}$, Kolehmainen $\mathrm{M}$, Toppinen L, Pihlajamäki J, Mykkänen H, Ågren JJ, Rauramaa R, Laakso M, Miettinen TA: Cholesterol synthesis prevails over absorption in metabolic syndrome. Translat Res 2007, 149:310-316.

87. Simonen $\mathrm{P}$, Kotronen $\mathrm{A}$, Hallikainen $\mathrm{M}$, Sevastianova $\mathrm{K}$, Makkonen J, Hakkarainen A, Lundbom N, Miettinen TA, Gylling H, Yki-Järvinen H: Cholesterol synthesis is increased and absorption decreased in nonalcoholic fatty liver disease independent of obesity. J Hepatol 2011, 54:153-159.
88. Pettinelli P, del Pozo T, Araya J, Rodrigo R, Araya AV, Smok G, Csendes A, Gutierrez L, Rojas J, Korn O, Maluenda F, Diaz JC, Rencoret G, Braghetto I, Castillo J, Poniachik J, Videla LA: Enhancement in liver SREBP-1c/PPAR-a ratio and steatosis in obese patients: Correlations with insulin resistance and $\mathrm{n}-3$ long-chain polyunsaturated fatty acid depletion. Biochim Biophys Acta 2009, 1792:1080-1086

89. Alenezi MY, Marcil M, Blank D, Sherman M, Genest J: Is the decreased high-density lipoprotein cholesterol in the metabolic syndrome due to cellular lipid efflux defect? J Clin Endocrinol Metab 2004, 89:761-764.

90. Jeppesen J, Hansen TW, Rasmussen S, Ibsen H, Torp-Pedersen C: Metabolic syndrome, low-density lipoprotein cholesterol, and risk of cardiovascular disease: A population-based study. Atherosclerosis 2006, 189:369-374.

91. Subramanian S, Han CY, Chiba T, McMillen TS, Wang SA, Haw A, Kirk EA, O'Brien KD, Chait A: Dietary cholesterol worsens adipose tissue macrophage accumulation and atherosclerosis in obese LDL receptordeficient mice. Arterioscler Thromb Vasc Biol 2008, 28:685-691.

92. Strömblad G, Björntorp P: Reduced hepatic insulin clearance in rats with dietary-induced obesity. Metabolism 1986, 35:323-327.

93. Azain MJ, Ontko JA: An explanation for decreased ketogenesis in the liver of the obese Zucker rat. Am J Physiol 1989, 257:R822-R828.

94. Pihlajamäki J, Gylling H, Miettinen TA, Laakso M: Insulin resistance is associated with increased cholesterol synthesis and decreased cholesterol absorption in normoglycemic men. J Lipid Res 2004, 45:507-512.

95. Lewis GF, Rader DJ: New insights into the regulation of HDL mtabolism and reverse cholesterol transport. Circul Res 2005, 96:1221-1232.

96. Kashyap SR, Diab DL, Baker AR, Yerian L, Bajaj H, Gray-McGuire C Schauer PR, Gupta M, Feldstein AE, Hazen SL, Stein CM: Triglyceride levels and not adipokine concentrations are closely related to severity of nonalcoholic fatty liver disease in an obesity surgery cohort. Obesity 2009, 17:1696-1701.

97. Li ZZ, Berk M, Mclntyre TM, Feldstein AE: Hepatic lipid partitioning and liver damage in nonalcopholic fatty liver disease. Role of stearoyl-CoA desaturase. J Biol Chem 2009, 284:5637-5664.

98. Stienstra R, Saudale F, Duval C, Keshthar S, Groener JEM, van Rooijen N, Staels B, Kersten B, Müller M: Kupffer cells promote hepatic steatosis via interleukin-1 $\beta$-dependent suppression of peroxisome proliferatoractivated receptor a activity. Hepatol 2010, 51:511-522.

99. Flamment M, Kammoun HL, Hainault I, Ferré P, Foufelle F: Endoplasmic reticulum stress: a new actor in the development of hepatic steatosis. Curr Op Lipidol 2010, 21:239-246.

100. Wang D, Wei YR, Pagliassotti MJ: Saturated fatty acids promote endoplasmic reticulum stress and liver injury in rats with hepatic steatosis. Endocrinology 2006, 147:943-951.

101. Aridor M, Balch WE: Integration of endoplasmic reticulum signaling in health and disease. Nat Med 1999, 5:745-751.

102. Ernster L, Siekevitz P, Palade GE: Enzyme-structure relationships in the endoplasmic reticulum of rat liver. A morphological and biochemical study. J Cell Biol 1962, 15:541-562.

103. Bell RM, Ballas LM, Coleman RA: Lipid topogenesis. J Lipid Res 1980, 22:391-403.

104. Higgins JA, Hutson JL: The roles of Golgi and endoplasmic reticulum in the synthesis and assembly of lipoprotein lipids in rat hepatocytes. J Lipid Res 1984, 24:1295-1305.

105. Lapierre LR, McLeod RS: Regulation of hepatic production of lipoproteins containing apolipoprotein B by ER-associated degradation. Futur Lipidol 2007, 2:173-184

106. Grattagliano I, Palmieri VO, Portincasa P, Moschetta A, Palasciano G: Oxidative stress-induced risk factors associated with the metabolic syndrome: a unifying hypothesis. J Nutr Biochem 2008, 19:491-504.

107. Kolwankar D, Vuppalanchi R, Ethell B, Jones DR, Wrighton SA, Hall SD, Chalasani N: Association between nonalcoholic hepatic steatosis and hepatic cytochrome P-450 3A activity. Clin Gastroenterol Hepatol 2007, 5:388-393

108. García Puig J, Martínez MA: Hyperuricemia, gout and the metabolic syndrome. Curr Op Rheumatol 2008, 20:187-191.

109. Nakagawa T, Tuttle KR, Short RA, Johnson RJ: Hypothesis: fructose-induced hyperuricemia as a causal mechanism for the epidemic of the metabolic syndrome. Nat Clin Pract Nephrol 2005, 1:80-86. 
110. Desco MC, Asensi M, Márquez R, Martínez-Valls J, Vento M, Pallardó FV, Sastre J, Viña J: Xanthine oxidase is involved in free radical production in type 1 diabetes. Protection by allopurinol. Diabetes 2002, 51:1118-1124.

111. Guerrero-Romero F, Rodríguez-Morán M: Low serum magnesium levels and metabolic syndrome. Acta Diabetol 2002, 39:209-213.

112. Kennedy ML, Failla ML: Zinc metabolism in genetically obese (ob/ob) mice. J Nutr 1987, 117:886-893.

113. Bozzini C, Girelli D, Olivieri O, Martinelli N, Bassi A, de Matteis G, Tenuti I, Lotto V, Friso S, Pizzolo F, Corrocher R: Prevalence of body iron excess in the metabolic syndrome. Diabet Care 2005, 28:2061-2063.

114. Mojiminiyi OA, Marouf $\mathrm{R}$, Abdella NA: Body iron stores in relation to the metabolic syndrome, glycemic control and complications in female patients with type 2 diabetes. Nutr Metab Cardiovasc Dis 2008, 18:559-566.

115. Yanoff LB, Menzie CM, Denkinger B, Sebring NG, McHugh T, Remaley AT, Yanovski JA: Inflammation and iron deficiency in the hypoferremia of obesity. Int J Obesity 2007, 31:1412-1419.

116. Faintrenie $G$, Géloën A: Lactate production by white adipocytes in relation to insulin sensitivity. Am J Physiol 1996, 270:C1061-C1066.

117. Marina Morales L, Campos G, Ryder E, Casanova A: Insulin and lipogenesis in rat adipocytes. II. Effect of high levels of insulin and glucose on lipid synthesis in isolated rat adipocytes. Biochem Biophys Res Commun 1994, 199:1151-1157.

118. Kabashima T, Kawaguchi T, Wadzinski BE, Uyeda K: Xylulose 5-phosphate mediates glucose-induced lipogenesis by xylulose 5-phosphate-activated protein phosphatase in rat liver. Proc Nat Acad Sci USA 2003, 100:5107-5112.

119. Romero MM, Grasa MM, Esteve M, Fernández-López JA, Alemany M: Semiquantitative RT -PCR measurement of gene expression in rat tissues including a correction for varying cell size and number. Nutr Metab 2007, $4: 26$.

120. Markan KR, Jurczak MJ, Brady MJ: Stranger in a strange land: Roles of glycogen turnover in adipose tissue metabolism. Mol Cell Endocrinol 2010, 318:54-60.

121. Lawrence JC, James C, Hiken JF: Control of glycogen synthase by insulin and isoproterenol in rat adipocytes. Changes in the distribution of phosphate in the synthase subunit in response to insulin and $\beta$ adrenergic receptor activation. J Biol Chem 1986, 261:669-677.

122. McClain DA, Hazel M, Parker G, Cooksey RC: Adipocytes with increased hexosamine flux exhibit insulin resistance, increased glucose uptake, and increased synthesis and storage of lipid. Am J Physiol 2005, 288: E973-E979.

123. Yea K, Kim J, Yoon JH, Kwon T, Kim JH, Lee BD, Lee HJ, Lee SJ, Kim J, Lee TG, Baek MC, Park HS, Park KS, Ohba M, Suh PG, Ryu SH: Lysophosphatidylcholine activates adipocyte glucose uptake and lowers blood glucose levels in murine models of diabetes. J Biol Chem 2009, 284:33833-33840.

124. Wood IS, Wang B, Lorente-Cebrián S, Trayhurn P: Hypoxia increases expression of selective facilitative glucose transporters (GLUT) and 2deoxy-D-glucose uptake in human adipocytes. Biochem Biophys Res Commun 2007, 361:468-473.

125. Aarsland A, Chinkes D, Wolfe RR: Hepatic and whole-body fat synthesis in humans during carbohydrate overfeeding. Am J Clin Nutr 1997, 65:1774-1782.

126. Jungas RL, Bali G: Studies on the metabolism of adipose tissue. XVII. In vitro effects of insulin upon the metabolism of the carbohydrate and triglyceride stores of adipose tissue from fasted-refed rats. Biochemistry 1964, 3:1696-1702.

127. Taylor SI, Jungas RL: Regulation of lipogenesis in adipose tissue: The significance of the activation of pyruvate dehydrogenase by insulin. Arch Biochem Biophys 1974, 164:12-19.

128. Stich V, de Glisezinski I, Berlan M, Bulow J, Galitzky J, Harant I, Suljkovicova $H$, Lafontan M, Rivière D, Crampes F: Adipose tissue lipolysis is increased during a repeated bout of aerobic exercise. J Appl Physiol 2000, 88:1277-1283.

129. Fredholm BB, Karlsson J: Metabolic effects of prolonged sympathetic nerve stimulation in canine subcutaneous adipose tissue. Acta Physiol Scand 1970, 80:567-576.

130. DiGirolamo M, Newby FD, Lovejoy J: Lactate production in adipose tissue: a regulated function with extra-adipose implications. FASEB $J$ 1992, 6:2405-2412.
131. Heckler BK, Carey GB: Lactate production by swine adipocytes: Effects of age, nutritional status, glucose concentration, and insulin. Am J Physiol 1997, 272:E957-E966.

132. Qvisth V, Hagström-Toft E, Enoksson S, Bolinder J: Catecholamine regulation of local lactate production in vivo in skeletal muscle and adipose tissue: Role of $\beta$-adrenoreceptor subtypes. J Clin Endocrinol Metab 2008, 93:240-246.

133. Hilpert $P$, Fleischmann RG, Kempe D, Bartels $H$ : The Bohr effect related to blood and erythrocyte pH. Am J Physiol 1963, 205:337-340.

134. Hosogai N, Fukuhara A, Oshima K, Miyata Y, Tanaka S, Segawa K, Furukawa S, Tochino Y, Komuro R, Matsuda M, Shimomura I: Adipose tissue hypoxia in obesity and its impact on adipocytokine dysregulation. Diabetes 2007, 56:901-911.

135. Attie AD, Scherer PE: Adipocyte metabolism and obesity. J Lipid Res 2009, 50:S395-S399.

136. Lavrovsky Y, Chatterjee B, Clark RA, Roy AK: Role of redox-regulated transcription factors in inflammation, aging and age-related diseases. Exp Gerontol 2000, 35:521-532.

137. Schmidt-Nielsen K: Energy metabolism. Animal Physiology. Adaptation and Environment Cambridge: Cambridge University Press; 1975, 208-258.

138. Trayhurn P, Wood IS: Adipokines: inflammation and the pleiotropic role of white adipose tissue. Br J Nutr 2004, 92:347-355.

139. Alemany $M$ : The defense of adipose tissue against excess substrateinduced hyperthrophia: Immune system cell infiltration and arrested metabolic activity. J Clin Endocrinol Metab 2011, 96:66-68.

140. Foster DO, Frydman ML: Nonshivering thermogenesis in the rat. II. measurements of blood flow with microspheres point to brown adipose tissue as the dominant site of the calorigenesis induced by noradrenaline. Can J Physiol Pharmacol 1978, 56:110-122.

141. Girardier L: Brown fat: An energy dissipating tissue. In Mammalian Thermogenesis. Edited by: Girardier L, Stock MJ. London: Chapman and Hall; 1983:50-98.

142. Perkins MN, Rothwell NJ, Stock MJ, Stone TW: Activation of brown adipose tissue thermogenesis by the ventromedial hypothalamus. Nature 1981, 289:401-402.

143. Remesar X, Fernández-López JA, Savall P, Salas A, Díaz-Silva M, Esteve M, Grasa MM, Alemany M: Effect of oral oleoyl-estrone on adipose tissue composition in male rats. Int J Obesity 2002, 26:1092-1102.

144. Beneke G, Rakow L: The fat organ. Acta Endocrinol 1973, 71:S174-S176.

145. Frayn KN: Adipose tissue as a buffer for daily lipid flux. Diabetologia 2002, 45:1201-1210.

146. Cinti S: The adipose organ. Prostagl Leukotr Essent Fatty Ac 2005, 73:9-15.

147. Henrichot E, Juge-Aubry CE, Pernin AS, Pache JC, Velebit V, Dayer JM, Meda P, Chizzolini C, Meier CA: Production of chemokines by perivascular adipose tissue - A role in the pathogenesis of atherosclerosis? Arterioscler Thromb Vasc Biol 2005, 25:2594-2599.

148. Spiroglou SG, Kostopoulos CG, Varakis JN, Papadaki HH: Adipokines in periaortic and epicardial adipose tissue: differential expression and relation to atherosclerosis. J Atheroscler Thromb 2010, 17:115-130.

149. Sacks HS, Fain JN: Human epicardial adipose tissue: A review. Am Heart J 2007, 153:907-917

150. Ichiki T: Perivascular adipose tissue, a janus-faced regulator of vascular function. Cicul J 2010, 74:1300-1301.

151. Weisberg SP, McCann D, DeSai M, Rosenbaum M, Leibel RL, Ferrante AW: Obesity is associated with macrophage accumulation in adipose tissue. $J$ Clin Invest 2003, 112:1796-1808.

152. Duffaut C, Galitzky J, Lafontan M, Bouloumié A: Unexpected trafficking of immune cells within the adipose tissue during the onset of obesity. Biochem Biophys Res Commun 2009, 384:482-485.

153. Zuk PA, Zhu M, Ashjian P, de Ugarte DA, Huang Jl, Mizuno H, Alfonso ZC, Fraser JK, Benhaim P, Hedrick MH: Human adipose tissue is a source of multipotent stem cells. Mol Biol Cell 2002, 13:4279-4295.

154. Franco Lambert AP, Fraga Zandonai A, Bonatto D, Cantarelli Machado D, Pêgas Henriques JA: Differentiation of human adipose-derived adult stem cells into neuronal tissue: Does it work? Differentiation 2009, 77:221-228.

155. Mårin $P$, Andersson B, Ottoson M, Olbe L, Chowdhury B, Kvist H, Holm G, Sjöström L, Björntorp P: The morphology and metabolism of intraabdominal adipose tissue in men. Metabolism 1992, 41:1241-1248.

156. Ravikumar B, Carey PE, Snaar JEM, Deelchand DK, Cook DB, Neely RDG, English PT, Firbank MJ, Morris PG, Taylor R: Real-time assessment of 
postprandial fat storage in liver and skeletal muscle in health and type 2 diabetes. Am J Physiol 2005, 288:E789-E797.

157. Hattori K, Numata N, Ikoma M, Matsuzaka A, Danielson RR: Sex differences in the distribution of subcutaneous and internal fat. Hum Biol 1991, 63:53-63.

158. Shen W, Punyanitya M, Silva AM, Chen J, Gallagher D, Sardinha LB, Allison DB, Heymsfield SB: Sexual dimorphism of adipose tissue distribution across the lifespan: a cross-sectional whole-body magnetic resonance imaging study. Nutr Metab 2009, 6:17.

159. Richter EA, Hansen BF, Hansen SA: Glucose-induced insulin resistance of skeletal-muscle glucose transport and uptake. Biochem J 1988, 252:733-737.

160. Francini F, Castro MC, Gagliardino JJ, Massa ML: Regulation of liver glucokinase activity in rats with fructose-induced insulin resistance and impaired glucose and lipid metabolism. Can J Physiol Pharmacol 2009, 87:702-710.

161. Hirsch J, Han PW: Cellularity of rat adipose tissue: effects of growth, starvation, and obesity. J Lipid Res 1969, 10:77-82.

162. Björntorp P, Smith U: The effect of fat cell size on subcutaneous adipose tissue metabolism. Front Matrix Biol 1976, 2:37-61.

163. McLaughlin T, Deng A, Yee G, Lamendola C, Reaven G, Tsao PS, Cushman SW, Sherman A: Inflammation in subcutaneous adipose tissue: relationship to adipose cell size. Diabetologia 2010, 53:369-377.

164. Body DR: The lipid composition of adipose tissue. Prog Lipid Res 1988, 27:39-60.

165. Killinger DW, Strutt BJ, Roncari DA, Khalil MW: Estrone formation from dehydroepiandrosterone in cultured human breast adipose stromal cells. J Steroid Biochem Mol Biol 1995, 52:195-201.

166. Boulton KL, Hudson DU, Coppack SW, Frayn KN: Steroid hormone interconversions in human adipose tissue in vivo. Metabolism 1992, 41:556-559.

167. Quinkler M, Sinha B, Tomlinson JW, Bujalska IJ, Stewart PM, Arlt W: Androgen generation in adipose tissue in women with simple obesity A site-specific role for $17 \beta$-hydroxysteroid dehydrogenase type $5 . J$ Endocrinol 2004, 183:331-342.

168. Lee MJ, Fried SK, Mundt SS, Wang Y, Sullivan S, Stefanni A, Daugherty BL Hermanowski-Vosatka A: Depot-specific regulation of the conversion of cortisone to cortisol in human adipose tissue. Obesity 2008, 16:1178-1185.

169. Klein S, Coppack SW, Mohamed-Ali V, Landt M: Adipose tissue leptin production and plasma leptin kinetics in humans. Diabetes 1996, 45:984-987.

170. Foster DL, Nagatani S: Physiological perspectives on leptin as a regulator of reproduction: Role in timing puberty. Biol Reprod 1999, 60:205-215.

171. Barb CR, Barrett JB, Kraeling RR: Role of leptin in modulating the hypothalamic-pituitary axis and luteinizing hormone secretion in the prepuberal gilt. Dom Anim Endocrinol 2004, 26:201-214.

172. Wang Q, Bing C, Al Barazanji K, Mossakowaska DE, Wang XM, McBay DL, Neville WA, Taddayon M, Pickavance L, Dryden S, Thomas MEA, McHale MT, Gloyer IS, Wilson S, Buckingham R, Arch JRS, Trayhurn P, Williams G: Interactions between leptin and hypothalamic neuropeptide $\mathrm{Y}$ neurons in the control of food intake and energy homeostasis in the rat. Diabetes 1997, 46:335-341.

173. Oswal A, Yeo GSH: Appetite regulatory peptides - The leptin melanocortin pathway and the control of body weight: lessons from human and murine genetics. Obes Rev 2007, 8:293-306.

174. Zhang Y, Proenca R, Maffei M, Barone M, Leopold L, Friedman JM: Positional cloning of the mouse obese gene and its human homologue. Nature 1994, 372:425-431.

175. Leibel RL: The role of leptin in the control of body weight. Nutr Rev 2002, 60:S15-S19.

176. Oswal A, Yeo G: Leptin and the control of body weight: A review of its diverse central targets, signaling mechanisms, and role in the pathogenesis of obesity. Obesity 2010, 18:221-229.

177. Engeli S, Negrel R, Sharma AM: Physiology and pathophysiology of the adipose tissue renin-angiotensin system. Hypertension 2000, 35:1270-1277.

178. Hoffstedt J, Arvidsson E, Sjolin E, Wahlen K, Arner P: Adipose tissue adiponectin production and adiponectin serum concentration in human obesity and insulin resistance. J Clin Endocrinol Metab 2004, 89:1391-1396.

179. Yang WS, Lee WJ, Funahashi T, Tanaka S, Matsuzawa Y, Chao C-L, Chen C-L, Tai T-Y, Chuang L-M: Weight reduction icreases plasma levels of an adipose-derived anti-inflammatory protein, adiponectin. J Clin Endocrinol Metab 2001, 86:3815-3819.

180. Ouchi N, Walsh K: Adiponectin as an anti-inflammatory factor. Clin Chim Acta 2007, 380:24-30.

181. Saito K, Arata S, Hosono T, Sano Y, Takahashi K, Choi-Miura NH, Nakano Y, Tobe T, Tomita M: Adiponectin plays an important role in efficient energy usage under energy shortage. Biochim Biophys Acta 2006, 1761:709-716.

182. Bruce CR, Mertz VA, Heigenhauser GJF, Dyck DJ: The stimulatory effect of globular adiponectin on insulin-stimulated glucose uptake and fatty acid oxidation is impaired in skeletal muscle from obese subjects. Diabetes 2005, 54:3154-3160.

183. Civitarese AE, Ukropcova B, Carling S, Hulver M, DeFronzo RA, Mandarino L, Ravussin E, Smith SR: Role of adiponectin in human skeletal muscle bioenergetics. Cell Metab 2006, 4:75-87.

184. Mizuno H, Itoi Y, Kawahara S, Ogawa R, Akaishi S, Hyakusoku H: In vivo adipose tissue regeneration by adipose-derived stromal cells isolated from GFP transgenic mice. Cells Tiss Org 2008, 187:177-185.

185. Peckham SC, Entenman C, Carroll HW: The influence of a hypercaloric diet on gross body and adipose tissue composition in the rat. J Nutr 1962, 77:187-197.

186. Sorisky A, Magun R, Gagnon AM: Adipose cell apoptosis: death in the energy depot. Int J Obesity 2000, 24:S3-S7.

187. Alemany M, Fernández-López JA: Adipose tissue: something more than just adipocytes. Curr Nutr Food Sci 2006, 2:141-150.

188. Scherer PE: Adipose tissue. From lipid storage compartment to endocrine organ. Diabetes 2006, 55:1537-1545.

189. Poulos SP, Hausman DB, Hausman GJ: The development and endocrine functions of adipose tissue. Mol Cell Endocrinol 2010, 323:20-34.

190. Price ER, Krokfors A, Guglielmo CG: Selective mobilization of fatty acids from adipose tissue in migratory birds. J Exp Biol 2008, 211:29-34.

191. To WWK, Wong MWN: Body fat composition and weight changes during pregnancy and 6-8 months post-partum in primiparous and multiparous women. Aust NZ J Obstet Gynecol 2009, 49:34-38.

192. Juge-Aubry CE, Henrichot $E$, Meier CA: Adipose tissue: a regulator of inflammation. Best Pract Res Clin Endocr Metab 2005, 19:547-566.

193. Maury E, Brichard SM: Adipokine dysregulation, adipose tissue inflammation and metabolic syndrome. Mol Cell Endocrinol 2010, 314:1-16.

194. Rajala MW, Scherer PE: The adipocyte - At the crossroads of energy homeostasis, inflammation, and atherosclerosis. Endocrinology 2003, 144:3765-3773.

195. Meijer K, de Vries M, Al-Lahham S, Bruinenberg M, Weening D, Dijkstra M, Kloosterhuis N, van der Leij RJ, van der Want H, Kroesen BJ, Vonk R, Rezaee F: Human primary adipocytes exhibit immune cell function: Adipocytes prime inflammation independent of macrophages. PLoS One 2011, 6:e17154.

196. Cancello R, Clément $K$ : Is obesity an inflammatory illness? Role of lowgrade inflammation and macrophage infiltration in human white adipose tissue. Br J Obstet Gynaecol 2006, 113:1141-1147.

197. Lumeng CN, DeYoung SM, Bodzin JL, Saltiel AR: Increased inflammatory properties of adipose tissue macrophages recruited during diet-induced obesity. Diabetes 2007, 56:16-23.

doi:10.1186/1743-7075-8-74

Cite this article as: Alemany: Utilization of dietary glucose in the metabolic syndrome. Nutrition \& Metabolism 2011 8:74. 